\title{
Elektrik ve Grafik Tasarım: Ameli Elektrik Dergisi Kapaklarının Görsel Analizi
}

\section{Electricity and Graphic Design: Visual Analysis of Ameli Elektrik Magazine Covers}

\author{
Ardan Ergüven \\ Doç., Marmara Üniversitesi, Güzel Sanatlar Fakültesi, Grafik Bölümü \\ email: ardanerguven@gmail.com (DORCID ID: https://orcid.org/ 0000-0001-9331-3038
}

\author{
$\underset{\text { tor Authors \& Researchers }}{\text { iThticate }} \mathrm{Bu}$ makale bilimsel etik ve kurallara uygun hazırlanmış ve intihal incelemesinden geçirilmiştir. Etik kurul onayı \\ gerektirmemektedir. \\ Atıf (APA 6)/To cite this article \\ Ergüven, A. (2021). Elektrik ve grafik tasarım: Ameli Elektrik dergisi kapaklarının görsel analizi. Atatürk Üniversitesi Güzel Sanatlar Enstitüsü \\ Dergisi, 27(46), 231-240. https://doi.org/10.35247/ataunigsed.853908 \\ Makale Gönderim Tarihi/Received: 04/12/2020 \\ Makale Kabul Tarihi/Accepted: 12/01/2021 \\ Makale Yayın Tarihi/Published: 30/03/2021
}

Review Article/Derleme Makale

Öz

1925 y1lında yayınlanmaya başlayan Ameli Elektrik Dergisi, Türkiye'de posta ile gönderilen ilk dergi olmuștur. 1932'de 42.500 adet basılan dergi elektrik abonelerine dağıtılmakta, aynı zamanda elektrik tüketimi ve tutarını bildirmekteydi. Pek çok eve giren dergi, aynı zamanda güçlü bir ilan vasitası olarak elektrikle ilgili pek çok ürünün tanıtıldığı bir mecraya dönüşmüştür. Dergi kapağında yer alan illüstrasyonlar ise ev yaşamının ve sosyal rollerin elektrikle birlikte nasıl değiștiğini görmemize yardımcı olmuştur. Farklı tarzlardaki görsel üslupları zamanın estetik anlayıșını ve tüketim alıskanlıklarını sergilemistir. Ceșitli ürünleri tanıtmak, olayları veya öyküleri anlatmak için kullanılan illüstrasyonlarlar, yarattıkları duygusal ve düşünsel etkiler ile grafik tasarım alanında her zaman ișlevsel bir yere sahip olmuștur. $\mathrm{Bu}$ çalışmanın amacı toplumsal değişimin göstergeleri olarak Ameli Elektrik Dergisi'nin kapaklarında kullanılan illüstrasyonların görsel bir analizini yapmaktır.

Anahtar kelimeler: Ameli Elektrik Dergisi, Grafik Tasarım, İllüstrasyon, Kapak Tasarımı, Kadın Figürü, Sembolik Anlatım

\begin{abstract}
Ameli Electric Magazine which was launched in 1925, was the first magazine sent by mail in Turkey. The magazine, printed 42,500 copies in 1932 , was distributed to electricity subscribers, and at the same time reported electricity consumption and amount. Magazines, which have entered many homes, have also turned into a medium where many electrical products are promoted as a powerful advertising tool. The illustrations on the magazine cover helped us to see how home life and social roles change with electricity. Different types of visual styles have displayed the aesthetic understanding and consumption habits of the time. The illustrations used to introduce various products and tell the events or stories have always had a functional place in visual communication with their emotional and intellectual effects. The purpose of this study is to make a visual analysis of the illustrations used on the covers of Ameli Elektrik Magazine as indicators of social change
\end{abstract}

Keywords: Ameli Electric Magazine, Graphic Design, Illustration, Cover Design, Female Figure, Symbolic Expression

\section{Giris}

19. yüzyılda gerçekleşen Endüstri Devrimi ile birlikte üretimde insan gücünün yerini makineler almaya başlamış ve enerjiye duyulan ihtiyaç artmıştır. İlk başlarda buhar ve havagazı ile çalışan fabrikalar elektrik üretim ve dağıtım tesislerinin kurulmasından sonra zamanla elektrik enerjisine yönelmiş̧ir. Elektrik sayesinde teknoloji büyük bir hızla gelişmeye başlamış; elektrikle çalışan makineler, tramvaylar, lambalar, ev aletleri ve radyolar insan yaşamında ve alışkanlıklarında önemli değişimlere neden olmuştur.

Türkiye'de ilk kez kentsel ölçekte elektrik üretimi yapan Silahtarağa Elektrik Santrali 1914'de İstanbul'da faaliyete geçmiş, üretilen elektrik ilk önce İstanbul tramvaylarına ve Dolmabahçe Sarayı'na verilmiştir. Kömür enerjisi ile çalışan santral ilk yıllarda yalnızca Beyazıt, Sultanahmet, Fatih, Samatya, Eyüp, Beyoğlu, Hasköy, Beşiktaş, Arnavutköy, Yeniköy, Tarabya ve Büyükdere semtlerine elektik sağlayabiliyordu. Elektrik alan bu semtlerde ağırlıklı olarak Rumlar, Ermeniler, Museviler ve Levantenler yaşamaktaydı. 1923'de Türkiye Cumhuriyeti kurulduğunda yalnızca üç şehire elektrik veriliyor ve nüfusun \%94'ü bu hizmetten yararlanamıordu. Yedi y1l içinde farklı şehirlerde otuz yeni santral kurulmuştu. 1930'da elektrik üretimi 30345 kW saatten 282 milyon kW saate çıkmıştı (Çavdar, 1983, s. 691-692).

Hem küçük üretim tesislerinin Haliç'de olması, hem yer seçiminin şehir merkezinden çok uzak olmaması, hem de dönemin teknolojisinden kaynaklanabilecek enerji kayıplarını en aza indirgemesi açısından Silahtarağa elektrik santrali Haliç çevresindeki sanayileşme konusunda öncü bir girişim olmuştur (Aksoy, 2007, s. 42). Uygarlık göstergesi olan elektrik devreye girdikten sonra sanayi üretimi ile birlikte şehir hayatı ve şehirli bireyin tüketim alışkanlıkları da değişmeye başlamıştır. İstanbul'un modern bir dünya kentine dönüșmesinde elektrik önemli bir rol oynamıștır: Elektrikle birlikte geceleri aydınlatılan sokaklar ile meydanlar, İstanbul'da eğlence ve kültür hayatının canlanmasını sağlamış, elektrikli tramvay ile ulaşımın 
gelişmesi, müstakil evlerin yerini yüksek katlı apartmanların alması kentsel ölçekte büyük bir değişimin başlangıcı olmuştur. Günlük hayata giren elektrikle birlikte bu hizmetten yararlanan kurumların ve hanelerin sayısı hızla artmaya başlamıştır. 1920'lerde kurulan Fransızca karşılığı Société Anonyme Turque d'installations Electriques (SATIE) olan Tesisat-1 Elektrikiye Türk Anonim Şirketi 1924 yılında imzalanan anlaşmayla "yabancı ülkelerden getirtmek veya mahalinde imal etmek suretiyle her nevi elektrik ahizeleri, motorları ve malzemeleri alıp satmak, aydınlatma ve muharrik güç tesisleri kurmak, genellikle elektrik araç ve gereçleri ticareti ve elektrik tesisat işleri ile uğraşma" misyonunu edinmiştir (Okandan, 2016, s. 42).

\section{Yöntem}

$\mathrm{Bu}$ araştırma, betimsel modele dayalı nitel bir araştırmadır. Çalışmada kavramsal çerçeveyi belirlemek için literatür taraması yapılmıștır. Bu kapsamda 1925 ile 1934 yılları arasında basımı gerçekleşen Ameli Elektrik Dergisi'nin kapakları incelenmiş ve görsel anlatım yöntemleri analiz edilmiştir. Elektrik kavramının gerçek yaşamdan imgelerle gösterilmesi her zaman sınırlı bir çerçevede gerçekleşmiştir. Kapak görsellerinde öyküsel bir anlatım ile yer alan görüntüler, dönemin toplumsal olguları göz önüne alınarak yorumlanmıştır.

\section{Bulgular}

\subsection{Görsel Üslup}

Elektrikle ilgili dünyadaki gelişmeleri aktarmak, elektrik kullanımı hakkında bilgi vermek ve elektrikli alet kullanımını teşvik etmek amacıyla İstanbul Elektrik ve Tramvay Şirketleri "Ameli Elektrik" isimli bir dergi çıkartmaya başlar ve elektrik abonelerine bu dergiyi gönderir. 1925'ten 1934 yılına kadar yayımlanmaya devam eden bu dergide haberler, deneme yazıları, öyküler, elektrikli aletlerin nasıl kullanılmasına dair bilgiler ve reklamlar büyük yer tutar. "Ameli Elektrik" dergisi bir tüketim kültürü yaratmaya çalışmıştır. Fransızca ve Osmanlıca olarak basılan dergide elektrikli aletlerin kullanıldı̆̆ 1 bir ortamda yaşayan modern aileler ile modern ev kadınları için pratik bilgilere ve tariflere yer verilmiştir (Akçura, 2002, s. 137-138).

Derginin ilk sayılarının kapaklarında, elektriğin ne olduğuna ve nasıl kullanıldığına dair betimleyici bir üslup benimsenmiş; karikatürü andıran çizimlerde İstanbul'dan manzaralar, sokaklar, elektrik santralleri ve lambalar gösterilmiştir. Derginin 1925 Aralık tarihli ilk sayısının kapak düzeninde köşelerinde süslemeler yer alan bir bordür içinde "Ameli Electric” başlığı altında Silahtarağa Elektrik Santrali’nin çizimi yer almakta, "L'électricité a la portée de tout le monde" (Elektriğe herkes erişebilir) ibaresinin hemen altında ise Türk Bayrağı'nın sembolü olan ay ve yıldıza asılı bir lamba, arka planda camilerin ve boğazın yer aldığı İstanbul manzarasını aydınlatmaktadır. Sol tarafta yer alan minare ile sağ tarafta yer alan kagir ev ise manzarayı çerçevelerken aynı zamanda eski İstanbul imgesine gönderme yapmaktadır (Görsel 1).

\section{Görsel 1}

Ameli Elektrik Dergisi, 1925 Aralık Sayısı

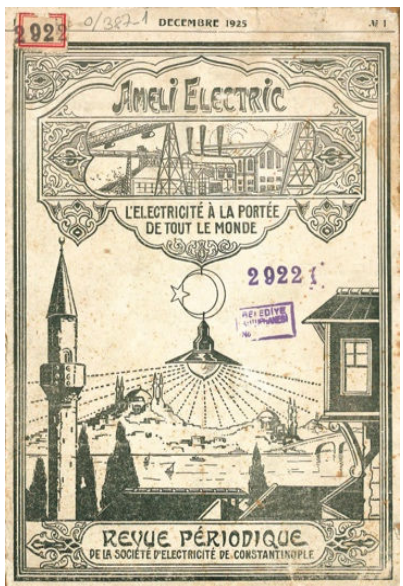

(Ameli, 1925).

Tarihi ve mimari özellikleri nedeni ile tarihi yarımada manzarası İstanbul konulu resimlerin öne çıkan öznelerinden biri olmuştur. Derginin 1926 tarihli Haziran sayısının kapağında bu manzaranın Karaköy'den görünümü ve Galata Köprüsü yer almaktadır (Görsel 2). Ön planda tepede parlayan sokak lambası adeta geceyi gündüze çevirirken, köprü üzerinde elektrik gücüyle ilerleyen tramvaylar modern bir kent izlenimi yaratmaktadır. Aynı resmin daha detaylı bir kopyası 1927 Mart sayısının kapağında yer almıştır (Görsel 3). 


\section{Görsel 2}

Ameli Elektrik Dergisi, 1926 Haziran Sayıs

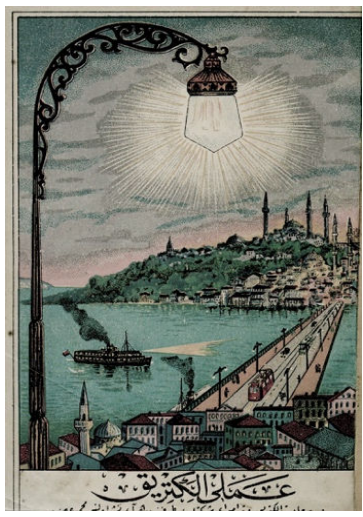

(Ameli, 1926).

\section{Görsel 3}

Ameli Elektrik Dergisi, 1927 Mart Sayıs

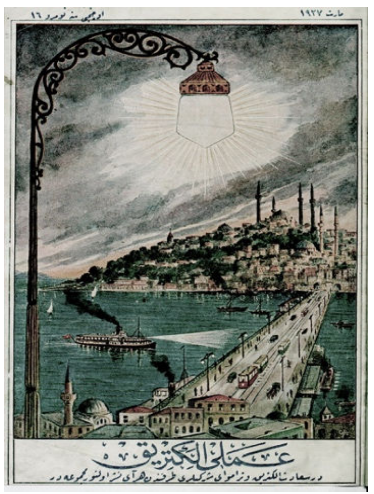

(Ameli, 1927).

Bu kompozisyon ile benzer bir mantığa sahip olan bir başka görsel 1928 tarihli Ağustos-Eylül sayısının kapağında kullanılmış, arka planda Aya Sofya'nın yer aldığı resimde alacakaranlığı aydınlatan lamba Ay’a benzetilmiştir. Böylece elektrik, yalnızca modern teknolojinin (ve yabancıların) sunduğu bir yenilik olarak gösterilmekle kalmamış, aynı zamanda kapakta yaratılan ulvi bir ifade ile muhafazakâr kesimin de onaylayacağı bir nimet olarak yansıtılmıştır. Litografi tekniği ile basılan kapakta cami ve gökyüzü firça darbeleri ile stilize edilmiştir (Görsel 4). 1926'da basılan Kasım sayısının kapağında ise köşelerinde Türk Bayrağı bulunan bir çerçeve içinde İstanbul'un ilk metrosunun (Tünel) yer aldığı ve aynı zamanda SATIE'nin yönetim binası olan Metro Han'ın iki renkli bir çizimi görülmektedir. Şematik bir ifadeye sahip olan bu bina imgesinin kullanılmasının nedeni, şirketin sermaye gücünün ve güvenirliğinin gösterilmesidir. Binanın üzerinde yer alan “Electricite, Tramways \& Tunnel” yazıları ile sunulan hizmetler ifade edilmektedir (Görsel 5).

\section{Görsel 4}

Ameli Elektrik Dergisi, 1928 A Ăustos Sayısı

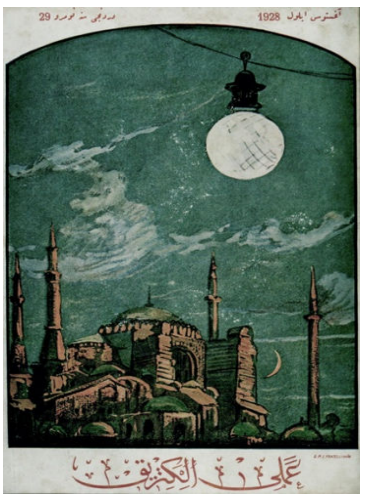

(Ameli, 1928). 


\section{Görsel 5}

Ameli Elektrik Dergisi, 1926 Kasım Sayısı

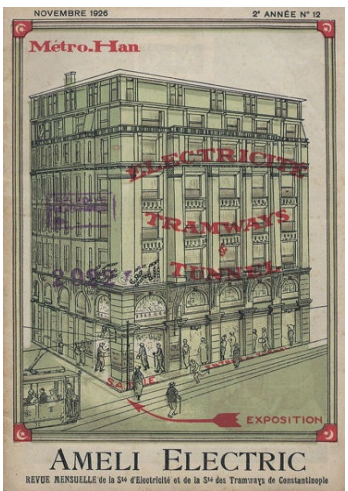

(Ameli, 1926).

\section{Görsel 6}

Ameli Elektrik Dergisi, 1928 Mayıs Sayısı

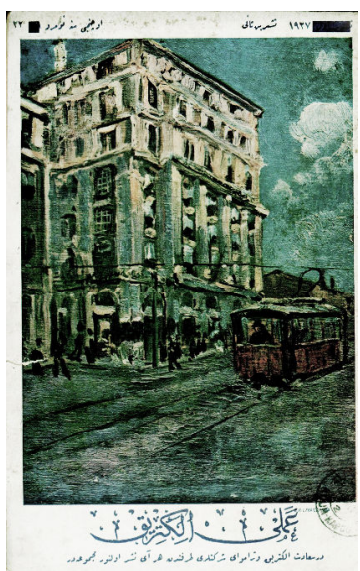

(Ameli, 1928).

$\mathrm{Bu}$ binanın izlenimci bir tarzda yapılmış bir başka resmi 1928'deki Mayıs sayısının kapağında yer almaktadır. Burada Metro-Han binası, Fransız ressam Claude Monet'in resimlerini andıran bir etkiyle daha canlı ve yaşayan bir mekân olarak gösterilmiştir (Görsel 6). Aynı yılın Haziran-Temmuz sayısının kapağında ise resimdeki perspektif, tramvaydan inmek üzere olan modern giyimli bir kadın figürünü işaret etmektedir (Görsel 7). Kompozisyonun geneline bakıldığında, soldaki ağacın ve tramvayın büyük bir bölümünün çerçevenin dışında yer alması, çalışmanın fotoğraftan yola çıkılarak hazırlandığı ya da fotoğrafa öykündüğü izlenimini vermektedir. İllüstrasyonun aksine fotoğraf kompozisyonu anlıktır ve bu nedenle gerçekçi görsel ifadelerde rastlantısal veya kontrol edilemeyen unsurlar yer alır.

\section{Görsel 7}

Ameli Elektrik Dergisi, 1928 Haziran Sayıs

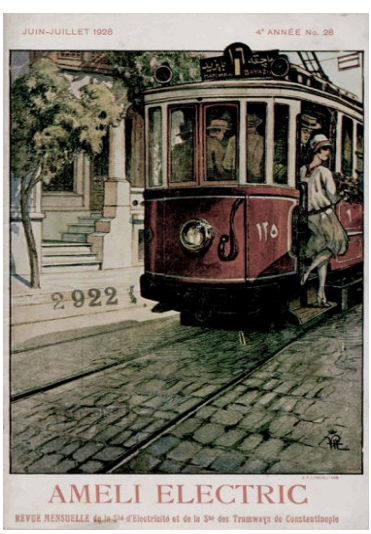

(Ameli, 1928). 


\subsection{Kadın Figürü Kullanımı}

Türkiye Cumhuriyeti'nin kurulduğu ilk yıllarda yayımlanmaya başlayan Ameli Elektrik Dergisi, modernleşme sürecindeki toplumun ve insanların yaşam stilini farklı tarzlardaki çizimler ve illüstrasyonlar ile yansıtmıştır. Özellikle dergi kapağında renkli olarak basılan kadın resimleri bu bakımdan öne çıkmaktadır. Cumhuriyetin ilk yıllarında basılan diğer dergilerde de kadınlar genellikle ev düzenini sağlayan, bakımlı ve modern bireyler olarak temsil edilmişlerdir (Kılıç ve Yılmaz, 2019, s. 2144).

Reklamlarda dikkat çeken ve cazibe yaratan bir imge olarak kadınların kullanılması 19. yüzyıl sonlarında Avrupa'da başlamıştır. Fransız afiş sanatçısı Jules Chéret'in afişlerinde yer alan kadın figürlerinin benzerleri kısa bir süre içinde çoğalmış, etkileri kısa bir süre içinde İstanbul'da hissedilmeye başlayan, Art Nouveau akımı sayesinde kadın imgesi, afişlerde dergilerde ve kitap kapaklarında öne çıkan görsel öğelerden biri olmuştur.

Bu bakımdan 1928'de basılan “Almanach de L’Améli Electric” başlıklı yayının kapağındaki illüstrasyonun, önceki örneklerden farklı bir mizansene sahip olduğu söylenebilir. Ön planda oldukça şık bir elektrikli masa lambasının yanında, üzerinde kırmızı bir yastık bulunan koltukta yüzüstü bırakılmış açık bir kitap görülmektedir. Arka planda ise ayakta duran güzel giyimli kadın, açık bir veranda kapısından servi ağaçlarının bulunduğu geniş bahçeye doğru bakmaktadır. Ağaçların arkasındaki dolunay geceyi aydınlatırken masa lambası da içeriyi aydınlatmaktadır. Bu sahnede kitap okumaya ara veren güzel ve bakımlı kadın, sanki eve gelecek kocasının yolunu gözlüyormuş gibi görünmektedir (Görsel 8).

\section{Görsel 8}

Ameli Elektrik Dergisi Almană̆

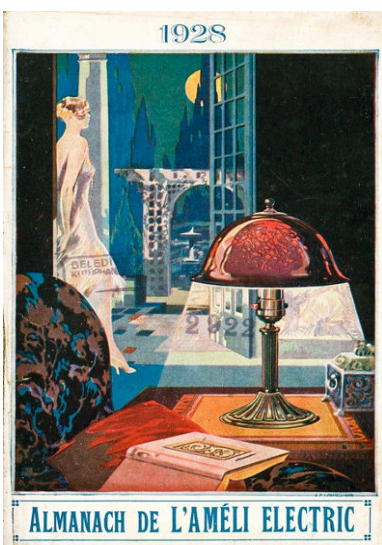

(Ameli, 1928).

1930 Mart-Nisan sayısının kapağında yer alan ve "Eggles" imzasını taşıyan resimde üzerinde gece elbisesi olan genç bir kadın, havaya doğru kaldırdığı sağ elinde bir mektup tutmakta; sol eliyle destek aldığ ve sırtını bize doğru hafifçe dönerek poz vermiştir. Bu sahnede elektriğin varlığını gösteren bir lamba, radyo veya vantilatör yer almamakta, fakat arka plandaki karanlık fon ve sol üst köşeden gelen aydınlık, bu mektubun akşam saatlerinde yazıldığı veya okunduğu izlenimini yaratmaktadır (Görsel 9).

\section{Görsel 9}

Ameli Elektrik Dergisi, 1930 Mart Sayıs

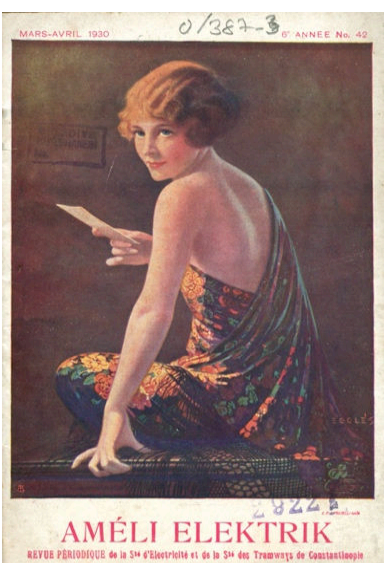

(Ameli, 1930). 
Elektrikli ürünlerin reklamlarında kadınlara yer verilmesinin bir başka nedeni de elektrik süpürgesi ve ütü gibi aletlerin genellikle ev işlerini kolaylaştırmaya yönelik olması ve bu sayede kadınların kendilerine daha fazla zaman ayırabilmesidir. 1931'in Kasım sayısının kapağı bu görüşü doğrulamaktadır: Kapaktaki illüstrasyonda, katlanmış ve üst üste dizilmiş çamaşırların yanında duran bir kadın figürü sol eliyle ütüyü işaret ederek bu zor işi elektrik sayesinde yapabildiğini bize göstermektedir. Arka planın düz olması, mobilya veya pencere gibi herhangi bir öğenin yer almaması, kapaktaki en koyu renge sahip olan ütü görselinin öne çıkmasına neden olmaktadır. Bu illüstrasyon öneki örneklerden farklı olarak reklamlara özgü görsel anlatım diline daha yakındır (Görsel 10).

\section{Görsel 10}

Ameli Elektrik Dergisi, 1930 Nisan Sayıs

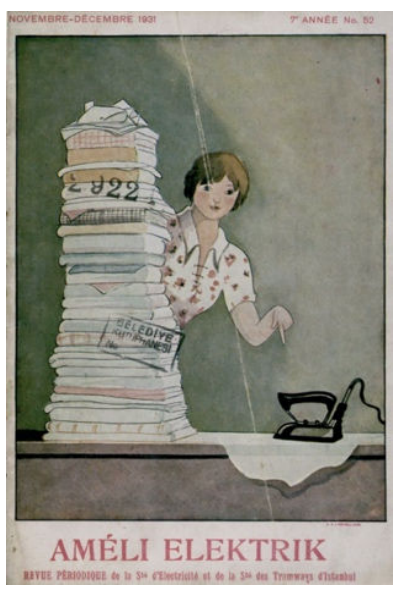

(Ameli, 1930).

Grafik tasarımın Türkiye'de profesyonel anlamda uygulanmaya başladığı 1920'li yıllarda genellikle herkesin ilk bakışta anlayabileceği ve öyküsü olan görüntüler kullanılmıştır. Görüntülere eşlik eden kelimeler, sloganlar ve marka isimleri ise ürünlerin veya hizmetlerin zihnimizdeki varlığını kalıcı hale getirmeye çalışmaktadır. Bu dönemin grafik tasarımlarında resimler genellikle ön planda olmuştur. Ameli Elektrik Dergisi'nin kapaklarında kullanılan imgeler ideal bir yaşamı yansıtmaktadır: 1928 Şubat sayısının kapağındaki illüstrasyonda bir anne elektrik lambası altında dikiş makinesini kullanırken kızı da onu izlemektedir. Sol alt köşede ise çalışmakta olan bir vantilatör görülmekte, annenin yüz ifadesinden mutlu ve huzurlu olduğu anlaşılmaktadır (Görsel 11).

\section{Görsel 11}

Ameli Elektrik Dergisi, 1928 Şubat Sayısı

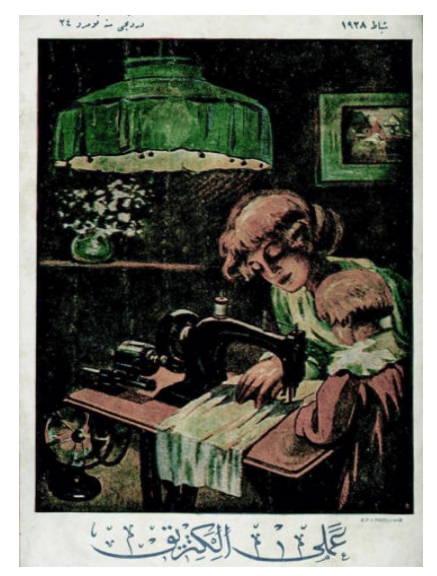

(Ameli, 1928).

\subsection{Sembolik Anlatım}

Görüntüler yazılardan daha hızlı algılandığı için tanıtım ve propaganda çalışmalarında her zaman ön plandadır. Görsel iletişimin temeli göstergelere dayanmaktadır: İnsanlara gösterilen imgeler ve kelimeler kendileri dişında başka şeylere de işaret ederler; böylece okuyucuların zihinlerinde belirli çağrışımlar yaratırlar. Amerikalı fỉlozof C. S. Pierce'a göre görüntüsel ve belirtisel göstergeler yerine geçtikleri şeyle doğal bir bağa sahiptir. Örneğin portresi yapılan kişinin portresi görüntüsel bir göstergedir. Bir yangının varlığını işaret eden duman ise belirtisel göstergedir. Marka veya uyarı işareti gibi şekiller ise anlamları öğrenilmek zorunda olan simgesel göstergelerdir (Berger, 2012, s. 81). 
Grafik tasarım 19. yüzyıl sonlarında Sanayi Devrimi'nin getirdiği yeni teknolojiler ve ticari olanaklar nedeniyle uzmanlaşma süreci ayrı bir meslek olarak ortaya çıkmıştır. 1922'de Amerikalı tipograf William A. Dwiggins, ortaya çıkan alanı tanımlamak için grafik tasarım terimini icat etmiştir (Britannica, t.y.). Grafik tasarım görsel bir cazibe yaratarak ürünlerin veya hizmetlerin tanıtılması ve pazarlanması için kullanılan bir görsel iletişim tekniğidir. Grafik tasarım imajları ve kelimeleri tek başına veya birlikte kullanarak çeşitli bilgileri ve mesajları görsel ifadelere dönüştürmekte; bu yöntem ile insanları bilgilendirmekte ve yönlendirmektedir. Grafik tasarım kavramının gelişmesinde baskı teknikleriyle beraber ekonomik ve kültürel gelişmelerin de önemli bir payı vardır.

Grafik tasarımlarda kullanılan imgeler hem üretim hem de algı süreçlerinin hızlandırılması için genellikle detaylardan arındırılmıştır. Ameli Elektrik Dergisi'nin 1930'lardan sonraki kapaklarında daha soyut grafik düzenlemeler ile birlikte stilize edilmiş kadın figürlerinin de kullanıldığı görülmektedir. 1931 Eylül-Ekim sayısında "Sous Les Flots de Lumière" (Işık Hüzmeleri Altında) başlı̆ğ ile basılan kapakta sol üstte ve altta olmak üzere iki farklı kaynaktan gelen 1şık demetleri kesişmekte; bu görsel fenomen açık sarı ve beyaz renkli alanlar ile yaratılmaktadır (Görsel 12). 1933 Ocak-Şubat sayısının kapağı da benzer bir tarzda tasarlanmıştır: Diğerinden farklı olarak bu kompozisyonda elektrikli su 1sıtıcı, vantilatör ve ütü illüstrasyonu yer almaktadır. Her iki tasarım da kompozisyon özellikleri ile kendi dönemleri içinde modern bir görünüme sahiptir (Görsel 13).

\section{Görsel 12}

Ameli Elektrik Dergisi, 1931 Eylül Sayısı

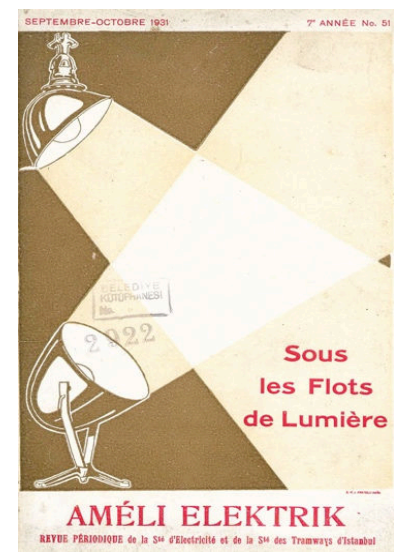

(Ameli, 1931).

\section{Görsel 13}

Ameli Elektrik Dergisi, 1933 Ocak Sayısı

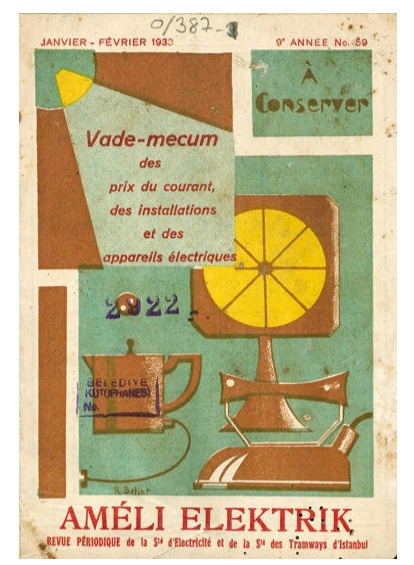

(Ameli, 1933).

1932 Temmuz-Ağustos ayısındaki kapağında ise bir vantilatör ile birlikte etekleri uçuşan bir kadın illüstrasyonu kullanılmıştır. Arka plandaki ağaç ile vantilatör arasındaki mecazi ilişki elektrik sayesinde kırların serinliğinin evlere geldiğini söylemektedir. Bu görselin dikkat çeken özellikleri arasında renkli alanların keskin bir şekilde birbirinden ayrılması gelmektedir. Önceki örneklerle karşılaştırıldığında gerçekçi bir gözle resmedilmeye çalışılan kadın imgesinin burada daha soyut bir tavırla stilize edildiği görülmektedir. Sağ tarafta dikkatimizi çeken elektrik fişinin boyutları göz önüne alındığında, grafik tasarıma özgü sembolik anlatım tekniğinin bu yıllarda önem kazanmaya başladığı fark edilmektedir (Görsel 14). 


\section{Görsel 14}

Ameli Elektrik Dergisi, 1932 Temmuz Sayıs

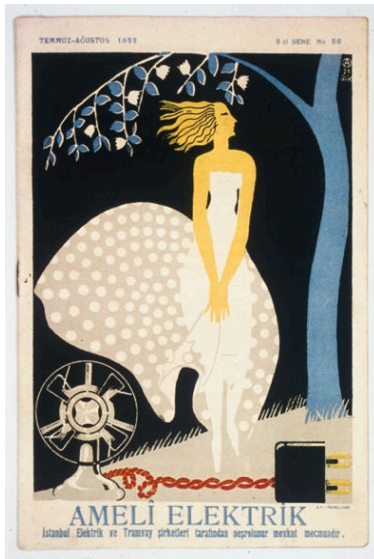

(Ameli, 1932).

1934 Ocak-Şubat ve Mayıs-Haziran sayılarının kapaklarında fırından yemek ve pasta çıkaran kadın figürleri yer almaktadır. İlk yıllarda gördügümüz cazibeli kadınların aksine bu illüstrasyonlarda kadınlar çizgi karakterler gibi gösterilmekte; yemek pişirme ve mutfakta vakit geçirme (ya da çalışma) eylemleri öne çıkmaktadır. Derginin ilk yıllarındaki örnekler ile karşılaştırıldığında bu illüstrasyonlarda kadınların daha aktif ve becerikli olarak resmedildiği anlaşılmakta; sosyolojik açıdan değerlendirildiğinde ise bu illüstrasyonlarda kadınlara belirli roller biçildiği gözden kaçmamaktadır (Görsel 15 ve Görsel 16).

\section{Görsel 15}

Ameli Elektrik Dergisi, 1934 Mayıs Sayısı

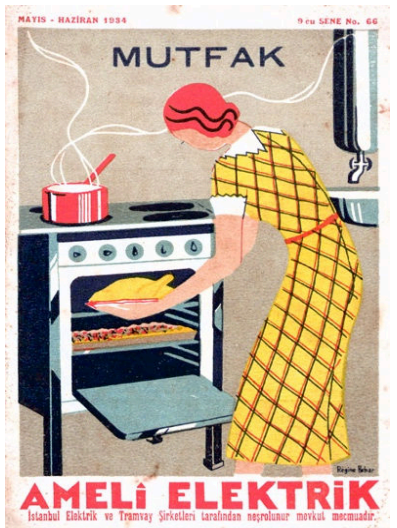

(Ameli, 1934).

\section{Görsel 16}

Ameli Elektrik Dergisi, 1934 Ocak Sayısı

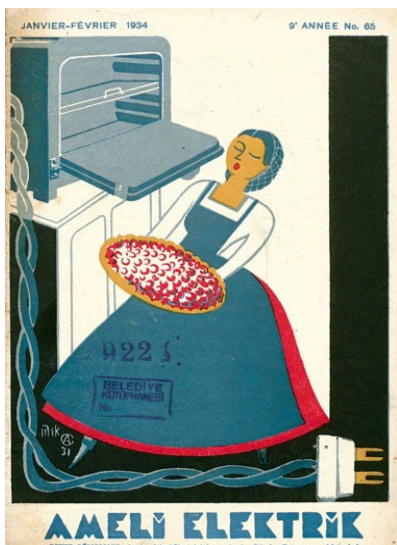

(Ameli, 1934). 


\section{Sonuç}

Görsel iletişim kurmamıza yardımcı olan her şeyin temelinde grafik tasarım vardır. Grafik tasarım görüntüler ile kelimeleri stratejik bir şekilde kullanan yaratıcı bir eylemdir; bir eylemin veya kavramın nasıl gösterileceğini ve sunulacağını belirler. Gerçek yaşamdaki görüntüleri veya kavramları, belirli yöntemler ile stilize ederek daha hızlı algılanabilir hale getirir; aynı zamanda çeşitli görsel öğeler kullanarak (renk, çizgi, nokta, ön plan, arka plan, perspektif vb.) mesajlar yaratır. Görüntüler, iletilen mesajın ve pazarlanan ürünün niteliği hakkında hedef kitleye fikirler verir. Etkili veya dikkat çekici başlıklar ise ürünlere yeni anlamlar yüklemenin etkili bir yöntemidir.

Afişlerde, gazetelerde veya dergilerde bir araya gelen görüntüler ile yazılar, ekonomik ve kültürel geçmişimizin kaydını tutarken, aynı zamanda o dönemlerde yaşayan insanların yaşam tarzlarını, duygularını ve davranışlarını yansıtmaktadır. Türkiye Cumhuriyeti'nin ilk yıllarında, kadınların yer aldığı basılı yayınlar ise değişen ve modern bir kimlik kazanan toplumun aynası olmuştur. Ameli Elektrik Dergisi’nin kapakları bu bakımdan Türkiye Cumhuriyeti'nin ilk yıllarında grafik tasarımın ve tüketim kültürün gelişimini gösteren kaynaklardan biri olarak önemini korumaktadır. 


\section{Kaynakça}

Akçura, G. (2002). Ivır zıvır tarihi III, Uzun metin sevelerden misiniz? OM Yayınevi.

Aksoy, A. (2007). Silahtară̆a elektrik santralı 1910-2004. İstanbul Bilgi Üniversitesi Yayınları.

Ameli. (1925, Aralık). Ameli elektrik dergisi [Fotoğraf]. https://archives.saltresearch.org/handle/123456789/ 129348

Ameli. (1926, Haziran). Ameli elektrik dergisi [Fotoğraf]. http://ataturkkitapligi.ibb.gov.tr/ataturkkitapligi/index. php

Ameli. (1926, Kasım). Ameli elektrik dergisi [Fotoğraf]. http://ataturkkitapligi.ibb.gov.tr/ataturkkitapligi/index. php

Ameli. (1927, Mart). Ameli elektrik dergisi [Fotoğraf]. http://ataturkkitapligi.ibb.gov.tr/ataturkkitapligi/index.php

Ameli. (1928). Ameli elektrik dergisi [Fotoğraf]. https://archives.saltresearch.org/handle/123456789/129103

Ameli. (1928, Şubat). Ameli elektrik dergisi [Fotoğraf]. https://archives.saltresearch.org/handle/123456789/ $\underline{129103}$

Ameli. (1928, Mayıs). Ameli elektrik dergisi [Fotoğraf]. http://ataturkkitapligi.ibb.gov.tr/ataturkkitapligi/index. php

Ameli. (1928, Haziran). Ameli elektrik dergisi [Fotoğraf]. http://ataturkkitapligi.ibb.gov.tr/ataturkkitapligi/index. php

Ameli. (1928, Ağustos). Ameli elektrik dergisi [Fotoğraf]. http://ataturkkitapligi.ibb.gov.tr/ataturkkitapligi/index. php

Ameli. (1930, Mart). Ameli elektrik dergisi [Fotoğraf]. https://archives.saltresearch.org/handle/123456789/129363

Ameli. (1930, Nisan). Ameli elektrik dergisi [Fotoğraf]. https://archives.saltresearch.org/handle/123456789/ 129363

Ameli. (1931, Eylül). Ameli elektrik dergisi [Fotoğraf]. https://archives.saltresearch.org/handle/123456789/ $\underline{129194}$

Ameli. (1932, Temmuz). Ameli elektrik dergisi [Fotoğraf]. http://ataturkkitapligi.ibb.gov.tr/ataturkkitapligi/index. php

Ameli. (1933, Ocak). Ameli elektrik dergisi [Fotoğraf]. https://archives.saltresearch.org/handle/123456789/ 129104

Ameli. (1934, Ocak). Ameli elektrik dergisi [Fotoğraf]. https://archives.saltresearch.org/handle/123456789/ $\underline{129270}$

Ameli. (1934, Mayıs). Ameli elektrik dergisi [Fotoğraf]. http://ataturkkitapligi.ibb.gov.tr/ataturkkitapligi/index. php

Berger, A. A. (2012). Kültür eleştirisi; Kültürel kavramlara giriş. Pinhan Yayınları.

Britannica. (t.y.). Neoclassial graphic design. https:/www.britannica.com/art/graphic-design/Neoclassicalgraphic-design

Çavdar, T. (1983). Türkiye'de enerji. Cumhuriyet dönemi Türkiye ansiklopedisi. İletişim Yayınları.

Kılıç, S. M., \& Yılmaz, D. V. (2019). Cumhuriyet dönemi kadın dergileri (1923-1992). Opus Uluslararası Toplum Araştırmaları.

Okandan, G. D. (2016). İşletmecilik tarihinde modern'den postmodern'e bir yolculuk: Silahtarağa elektrik santrali'nden Santral İstanbul'a süreklilik ve değişim. İstanbul Üniversitesi İşletme Fakültesi Dergisi, 45(0), 40-48. https://dergipark.org.tr/tr/pub/iuisletme/issue/30531/330282 